Article

\title{
Antimicrobial Resistance Profiles of Staphylococcus aureus Isolated from Meat Carcasses and Bovine Milk in Abattoirs and Dairy Farms of the Eastern Cape, South Africa
}

\author{
Abongile Pekana ${ }^{1}$ and Ezekiel Green ${ }^{2, *}$ \\ 1 Department of Biochemistry and Microbiology, University of Fort Hare, Alice 5700, South Africa; \\ 200600011@ufh.ac.za \\ 2 Department of Biotechnology and Food Technology, University of Johannesburg, Doornfontein 2028, \\ South Africa \\ * Correspondence: egreen@uj.ac.za; Tel.: +27-11-559-6793
}

Received: 15 August 2018; Accepted: 9 October 2018; Published: 11 October 2018

\begin{abstract}
Background: Staphylococcus aureus (S. aureus) occasionally threatens the life of the host as a persistent pathogen even though it is normal flora of humans and animals. We characterized drug resistance in S. aureus isolated from animal carcasses and milk samples from the abattoirs and dairy farms in the Eastern Cape Province. Methods: A total of 1000 meat swab samples and 200 raw milk samples were collected from selected abattoirs and dairy farms. S. aureus was isolated and positively identified using biochemical tests and confirmed by molecular methods. An antibiotic susceptibility test was performed on all isolates for 14 antibiotics and correspondent genes were detected. Results: Of the 1200 samples collected, 134 (11.2\%) samples were positive for $S$. aureus. Resistance ranged from $71.6 \%$ for penicillin G to $39.2 \%$ for tetracycline. A resistance gene (blaZ) was detected in $13(14.9 \%)$, while $m s r$ A was found in 31 (52.5\%) of S. aureus isolates. Conclusions: The present result shows the potential dissemination of multidrug-resistant $S$. aureus strains in the dairy farms and abattoirs in the Eastern Cape. Therefore, this implies that the organism may rapidly spread through food and pose serious public health risk.
\end{abstract}

Keywords: Staphylococcus aureus; meat; raw milk; antibiotics; antibiotic resistance genes

\section{Introduction}

Staphylococci asymptomatically colonizes the skin and mucous membranes in the nostrils of humans and animals [1-5]. This is an important outcome, bearing in mind the fact that nasal carriage of Staphylococcus aureus has been associated with subsequent infection [5]. Several studies have reported the identification of coagulase-positive and coagulase-negative species in warm-blooded animals [2,3,6-9]. Carriers are therefore an important source infection spread in communities. S. aureus (Staphylococcus aureus) causes diseases in humans and animals which include toxic syndrome and staphylococcal food poisoning (SFP) [10-13]. The work of Hatakka et al. [14] has revealed that S. aureus in meat is a result of improper hygienic practices during handling by the slaughter personnel during meat production.

South African studies have reported that a high percentage of the population largely depends on beef and pork meat as a protein [15,16]. Additionally, some researchers have demonstrated that infections with antibiotic resistant strains are caused by foods contaminated with antibiotic resistant bacteria [17-19] making them an ideal vehicle for transmission of antibiotic resistance. 
Studies have reported that prolonged use and misuse of antimicrobial agents in agriculture, stock farming and in treatment of human diseases have resulted in rapid resistance of many bacteria to several antibiotics of different classes [20-22]. The development of antibiotic resistance has been observed for a variety of antimicrobial agents which include aminoglycosides, macrolides, glycopeptides, fluoroquinolones and tetracyclines [23]. Many antibiotic resistance genes play a role in S. aureus resistance and these include macrolide resistance encoded by the erm gene, aphA3 and sat genes for kanamycin and streptomycin resistance and $a c c A-a p h D$ and tet genes for gentamicin, tobramycin and tetracycline resistance [24,25].

There is paucity of information on the molecular characterization of S. aureus in most developing countries $[23,26]$ especially in the Eastern Cape province of South Africa. Better understanding of S. aureus antibiotic susceptibility profiles and molecular characterization of genes causing resistance are of paramount importance for initiating effective control measures and reducing staphylococcal infections $[23,26]$. The aim of the study was to identify and characterize antibiotic resistance susceptibility patterns including antibiotic resistance genes in S. aureus strains isolated from selected dairy farms and abattoirs in the Eastern Cape Province, South Africa.

\section{Materials and Methods}

A total of two hundred milk samples were collected from cows with subclinical and clinical mastitis cases over 6 months at Dairy Farm A (100 samples) and Dairy Farm B (100 samples). Milk samples were collected using the method of Caine et al. [27]. Briefly, in each milking station there is a small collection bottle with a small hole that is opened and closed using a tap. The bottles were properly washed and used for sampling another cows' milk. All the milk samples were stored on ice and transported to the Biochemistry and Microbiology Laboratory for analysis.

A total of 1000 meat swab samples were collected from cow carcasses, pig carcasses and sheep carcasses in four selected abattoirs according to the method of Pearce and Bolton [18]. Permission to collect swab samples was obtained from abattoir managers. Samples were collected from the available animal carcasses during a period of 10 months (August 2015 to May 2016). Samples were collected using a sterile swab rinsing kit containing $10 \mathrm{~mL}$ isotonic buffer rinse solution, after the gastrointestinal tract was removed. A $100 \mathrm{~cm}^{2}$ sterile disposable plastic template (Analytical Diagnostics, USA) was used to mark the area for swabbing. A total of 500 meat swab samples were collected from cow carcasses, 300 meat swab samples from sheep carcasses and 200 meat swab samples from pig carcasses. Each animal carcass was sampled in four areas which included rump, flank, brisket, and neck, and isolates from those four areas were counted consecutively. The meat swab samples were then stored on ice and transported to the Biochemistry and Microbiology Laboratory for analysis.

\subsection{Isolation of S. aureus Milk and Meat Samples}

Ten microliters of each milk sample were inoculated onto Baird Parker Agar (Oxoid; ThermoScientific, England, UK) and incubated at $37{ }^{\circ} \mathrm{C}$ for $24-48 \mathrm{~h}$. Meat swab samples were also inoculated onto the same culture media (in-house method) and incubated for the same period. Presumptive grey-black colonies surrounded by opaque halo of precipitation on Baird Parker agar were regarded as presumptive $S$. aureus isolates and were subjected to biochemical identification.

\subsection{Biochemical Identification and DNA Extraction}

Gram-staining, catalase test and oxidase test were performed according to the method of Health Protection Agency [28-30] for biochemical identification of the organism. DNA extraction was performed based on the procedure of Maugeri et al. [31]. Briefly, a loop full 24-h culture of S. aureus colonies grown onto Nutrient Agar plates were suspended into $200 \mu \mathrm{L}$ of sterile nuclease free water and vortexed for 2 min using MS2 Minishaker (Digisystem Laboratory instruments Inc., New Taipei City, Taiwan) and the cells were lysed using a heat Dri-Block DB.2A (Technc, Johannesburg, South Africa) for $15 \mathrm{~min}$ at $100{ }^{\circ} \mathrm{C}$. The pellet was removed by centrifugation at $10,000 \mathrm{rpm}$ for $5 \mathrm{~min}$ using a MiniSpin 
microcentrifuge (ThermoFisher Scientific, Waltham, MA, USA) kept at $4{ }^{\circ} \mathrm{C}$. The supernatant was transferred in new Eppendorf tubes and used for PCR reactions.

\subsection{Bacterial Identification}

The nuc Gene Amplification

The isolates were confirmed by PCR amplification of the $n u c$ gene encoding the thermonuclease enzymes with the oligonucleotide primers shown in Table 1 . The total PCR reaction volume of $25 \mu \mathrm{L}$ containing $12 \mu \mathrm{L}$ of master mix (Kapa Biosystems, Johannesburg, South Africa) (containing, DNA Taq polymerase, dNTPs, $\mathrm{MgCl}_{2}$ and PCR buffer), $5 \mu \mathrm{L}$ DNA template, $1 \mu \mathrm{L}$ of the forward and reverse primers, and $6 \mu \mathrm{L}$ of nuclease free water was used. Polymerase chain reaction (PCR) was performed using MyCycler ${ }^{\mathrm{TM}}$ (Biorad, Cape Town, South Africa). A total of 35 PCR cycles were run under the following conditions: DNA denaturation at $94^{\circ} \mathrm{C}$ for $1 \mathrm{~min}$, primer annealing at $55^{\circ} \mathrm{C}$ for $0.5 \mathrm{~min}$, and DNA extension at $72{ }^{\circ} \mathrm{C}$ for $1.5 \mathrm{~min}$. The final cycle was at $72{ }^{\circ} \mathrm{C}$ for $5 \mathrm{~min}$. The PCR products were stored at $4{ }^{\circ} \mathrm{C}$ until they were collected. Amplicons were resolved on $1.5 \%$ agarose gel containing $5 \mu \mathrm{L}$ Ethidium bromide in $1 \times$ TAE buffer $\mathrm{pH} 8.0$ for $1 \mathrm{~h}$ at $100 \mathrm{~V}$ before being visualized and captured under Alliance 4.7 transilluminator (UVITEC Limited, Cambridge, UK).

\subsection{Antibiotic Susceptibility Testing}

A disk diffusion antibiotic susceptibility test was conducted according to the Clinical and Laboratory Standards Institute [32]. Bacterial suspensions were prepared in $2.5 \mathrm{~mL}$ of Mueller-Hinton broth and the turbidity was adjusted to meet 0.5 McFarland turbidity standards $\left(\sim 1.5 \times 10^{8} \mathrm{cfu} / \mathrm{mL}\right)$. The isolates were inoculated onto a Mueller-Hinton Agar plate and tested against a panel of fourteen antibiotics (Table 2) and results were interpreted according to the Clinical and Laboratory Standards Institute [32]. Staphylococcus aureus ATCC 25923 was used as a positive control. A dendrogram was generated by unweighted pairwise grouping with mathematical averaging (UPGMA). Isolates were considered as belonging to a common cluster when the resistance pattern differed by $\leq 5$ antibiotics.

Table 1. Oligonucleotide sequences used for polymerase chain reaction in the identification of Staphylococcus aureus and detection of antibiotic resistance genes.

\begin{tabular}{|c|c|c|c|c|}
\hline $\begin{array}{l}\text { Target } \\
\text { Gene }\end{array}$ & Oligonucleotide Sequence $\left(5^{\prime}-3^{\prime}\right)$ & $\begin{array}{l}\text { Amplicon } \\
\text { Size (bp) }\end{array}$ & PCR Conditions & Reference \\
\hline nuc & $\begin{array}{l}\text { GCG ATT GAT GGT GAT ACG GTT } \\
\text { CCA AGC CTT GAC GAA CTA AAG C }\end{array}$ & 255 & $\begin{array}{l}\text { PCR was performed under the following } \\
\text { conditions: One cycle of } 95^{\circ} \mathrm{C} \text { for } 5 \mathrm{~min} \text {, } \\
35 \text { cycles of } 95^{\circ} \mathrm{C} \text { for } 30 \mathrm{~s}, 55^{\circ} \mathrm{C} \text { for } 30 \mathrm{~s} \text {, } \\
\text { and } 72^{\circ} \mathrm{C} \text { for } 1 \mathrm{~min}, 1 \mathrm{cycle} \text { of } 72^{\circ} \mathrm{C} \text { for } \\
10 \mathrm{~min} \text {. }\end{array}$ & [33] \\
\hline mecA & $\begin{array}{l}\text { AAA ATC GAT GGT AAA GGT TGG C } \\
\text { AGT TCT GCA GTA CCG GAT TTG C }\end{array}$ & 533 & $\begin{array}{l}\text { Amplification was carried out using } \\
40 \text { cycles of amplification at } 94^{\circ} \mathrm{C} \text { for } 30 \mathrm{~s} \text {, } \\
55^{\circ} \mathrm{C} \text { for } 30 \mathrm{~s} \text {, and } 72^{\circ} \mathrm{C} \text { for } 1 \mathrm{~min} \text {; } \\
\text { this reaction was followed by } 5 \mathrm{~min} \text { of an } \\
\text { additional extension at } 72^{\circ} \mathrm{C} \text {. }\end{array}$ & [6] \\
\hline blaZ & $\begin{array}{l}\text { ACT TCA ACA CCT GCT GCT TTC } \\
\text { TGA CCA CTT TTA TCA GCA ACC }\end{array}$ & 173 & $\begin{array}{l}\text { PCR mixture was subjected to } 35 \text { cycles of } \\
\text { amplification. The conditions for each cycle } \\
\text { were: Denaturation for } 1 \mathrm{~min} \text { at } 94^{\circ} \mathrm{C} \text {, } \\
\text { annealing for } 1 \mathrm{~min} \text { at } 54^{\circ} \mathrm{C} \text {, and primer } \\
\text { extension for } 1 \mathrm{~min} \text { at } 72^{\circ} \mathrm{C} \text {. Finally, } \\
\text { the reaction was incubated at } 72^{\circ} \mathrm{C} \text { for } \\
10 \text { min. }\end{array}$ & [34] \\
\hline$a c c(6)-a p h(2)$ & $\begin{array}{l}\text { TTG GGA AGA TGA AGT TTT TAG A } \\
\text { CCT TTA CTC CAA TAA TTT GGC T }\end{array}$ & 174 & $\begin{array}{l}95^{\circ} \mathrm{C} \text { for } 5 \text { min was followed by } 30 \text { cycles } \\
\text { of denaturation at } 95^{\circ} \mathrm{C} \text { for } 60 \mathrm{~s} \text {, and then } \\
\text { annealed at } 54^{\circ} \mathrm{C} \text { for } 2 \mathrm{~min} \text {, and after that } \\
\text { extended at } 72^{\circ} \mathrm{C} \text { for } 2 \mathrm{~min} \text {. Finally, } \\
\text { an additional extension was achieved for } \\
5 \text { min at } 72^{\circ} \mathrm{C} \text {. }\end{array}$ & [35] \\
\hline
\end{tabular}


Table 1. Cont

\begin{tabular}{|c|c|c|c|c|}
\hline $\begin{array}{l}\text { Target } \\
\text { Gene }\end{array}$ & Oligonucleotide Sequence $\left(5^{\prime}-3^{\prime}\right)$ & $\begin{array}{l}\text { Amplicon } \\
\text { Size (bp) }\end{array}$ & PCR Conditions & Reference \\
\hline $\begin{array}{c}a p h \\
\left(3^{\prime}\right)-1-I I I a\end{array}$ & $\begin{array}{l}\text { AAA TAC CGC TGC GTA } \\
\text { CAT ACT CTT CCG AGC AA }\end{array}$ & 242 & $\begin{array}{l}95^{\circ} \mathrm{C} \text { for } 5 \text { min was followed by } 30 \text { cycles } \\
\text { of denaturation at } 95^{\circ} \mathrm{C} \text { for } 30 \mathrm{~s} \text {, and then } \\
\text { annealed at } 54^{\circ} \mathrm{C} \text { for } 1 \mathrm{~min} \text {, and after that } \\
\text { extended at } 72{ }^{\circ} \mathrm{C} \text { for } 2 \mathrm{~min} \text {. Finally, } \\
\text { an additional extension was achieved for } \\
5 \text { min at } 72^{\circ} \mathrm{C} \text {. }\end{array}$ & [36] \\
\hline ant $\left(4^{\prime}\right)-I a$ & $\begin{array}{l}\text { AAT CGG TAG AAG CCC AA } \\
\text { GCA CCT GCC ATT GCT A }\end{array}$ & 135 & $\begin{array}{l}95^{\circ} \mathrm{C} \text { for } 3 \text { min was followed by } 30 \text { cycles } \\
\text { of denaturation at } 95^{\circ} \mathrm{C} \text { for } 60 \mathrm{~s} \text {, and then } \\
\text { annealed at } 54^{\circ} \mathrm{C} \text { for } 2 \mathrm{~min} \text {, and after that } \\
\text { extended at } 72^{\circ} \mathrm{C} \text { for } 2 \mathrm{~min} \text {. Finally, } \\
\text { an additional extension was achieved for } \\
5 \text { min at } 72^{\circ} \mathrm{C} \text {. }\end{array}$ & [36] \\
\hline erm $\mathrm{A}$ & $\begin{array}{l}\text { TAT CTT ATC GTT GAG AAG GGA TT } \\
\text { CTA CAC TTG GCT TAG GAT GAA A }\end{array}$ & 139 & $\begin{array}{l}95^{\circ} \mathrm{C} \text { for } 5 \text { min was followed by } 30 \text { cycles } \\
\text { of denaturation at } 95^{\circ} \mathrm{C} \text { for } 30 \mathrm{~s} \text {, and then } \\
\text { annealed at } 54^{\circ} \mathrm{C} \text { for } 1 \mathrm{~min} \text {, and after that } \\
\text { extended at } 72{ }^{\circ} \mathrm{C} \text { for } 2 \mathrm{~min} \text {. Finally, } \\
\text { an additional extension was achieved for } \\
5 \text { min at } 72^{\circ} \mathrm{C} \text {. }\end{array}$ & [35] \\
\hline erm $\mathrm{B}$ & $\begin{array}{l}\text { CTA TCT GAT TGT TGA AGA AGG ATT } \\
\text { GTT TAC TCT TGG TTT AGG ATG AAA }\end{array}$ & 142 & $\begin{array}{l}95^{\circ} \mathrm{C} \text { for } 5 \text { min was followed by } 30 \text { cycles } \\
\text { of denaturation at } 95^{\circ} \mathrm{C} \text { for } 30 \mathrm{~s} \text {, and then } \\
\text { annealed at } 54^{\circ} \mathrm{C} \text { for } 1 \mathrm{~min} \text {, and after that } \\
\text { extended at } 72{ }^{\circ} \mathrm{C} \text { for } 2 \mathrm{~min} \text {. Finally, } \\
\text { an additional extension was achieved for } \\
5 \text { min at } 72{ }^{\circ} \mathrm{C} \text {. }\end{array}$ & [37] \\
\hline erm C & $\begin{array}{l}\text { CTT GTT GAT CAC GAT AAT TTC C } \\
\text { ATC TTT TAG CAA ACC CGT ATT C }\end{array}$ & 190 & $\begin{array}{l}95^{\circ} \mathrm{C} \text { for } 5 \mathrm{~min} \text { was followed by } 30 \text { cycles } \\
\text { of denaturation at } 95^{\circ} \mathrm{C} \text { for } 30 \mathrm{~s} \text {, and then } \\
\text { annealed at } 54^{\circ} \mathrm{C} \text { for } 1 \mathrm{~min} \text {, and after that } \\
\text { extended at } 72^{\circ} \mathrm{C} \text { for } 2 \mathrm{~min} \text {. Finally, } \\
\text { an additional extension was achieved for } \\
5 \text { min at } 72^{\circ} \mathrm{C} \text {. }\end{array}$ & [35] \\
\hline msrA & $\begin{array}{l}\text { TCC AAT CAT TGC ACA AAA TC } \\
\text { AAT TCC CTC TAT TTG GTG GT }\end{array}$ & 163 & $\begin{array}{l}94^{\circ} \mathrm{C} \text { for } 5 \mathrm{~min}, 30 \text { cycles of } 94^{\circ} \mathrm{C} \text { for } 45 \mathrm{~s} \text {, } \\
50^{\circ} \mathrm{C} \text { for } 60 \mathrm{~s}, 72^{\circ} \mathrm{C} \text { for } 60 \mathrm{~s} \text {, final extension } \\
\text { at } 72{ }^{\circ} \mathrm{C} \text { for } 10 \mathrm{~min} .\end{array}$ & [35] \\
\hline tet $\mathrm{K}$ & $\begin{array}{l}\text { GTA GCG ACA ATA GGT AAT AGT } \\
\text { GTA GTG ACA ATA AAC CTC CTA }\end{array}$ & 360 & $\begin{array}{l}\text { Initial denaturation at } 94{ }^{\circ} \mathrm{C} \text { for } 3 \mathrm{~min}, 25 \\
\text { cycles of } 94^{\circ} \mathrm{C} \text { for } 1 \mathrm{~min} \text {, annealing at } 55^{\circ} \mathrm{C} \\
\text { for } 1 \mathrm{~min} \text {, and extension at } 72{ }^{\circ} \mathrm{C} \text { for } 1 \mathrm{~min} \text {. } \\
\text { The final extension was carried out at } 72^{\circ} \mathrm{C} \\
\text { for } 10 \mathrm{~min} \text {. }\end{array}$ & [37] \\
\hline tet $\mathrm{M}$ & $\begin{array}{l}\text { AGT GGA GCG ATT ACA GAA } \\
\text { CAT ATG TCC TGG CGT GTC TA }\end{array}$ & 158 & $\begin{array}{l}\text { Initial denaturation at } 94{ }^{\circ} \mathrm{C} \text { for } 3 \mathrm{~min}, 25 \\
\text { cycles of } 94^{\circ} \mathrm{C} \text { for } 1 \mathrm{~min} \text {, annealing at } 55^{\circ} \mathrm{C} \\
\text { for } 1 \mathrm{~min} \text {, and extension at } 72{ }^{\circ} \mathrm{C} \text { for } 1 \mathrm{~min} \text {. } \\
\text { The final extension was carried out at } 72^{\circ} \mathrm{C} \\
\text { for } 10 \mathrm{~min} \text {. }\end{array}$ & [37] \\
\hline
\end{tabular}

Detection of Antibiotic Resistance Genes of Staphylococcus aureus

The confirmed S. aureus isolates were screened for antibiotic resistance genes using the oligonucleotide primers and PCR conditions listed in Table 1. The total reaction volume of $25 \mu \mathrm{L}$ containing $12 \mu \mathrm{L}$ of master mix (Kapa Biosystems, Johannesburg, South Africa) (containing, DNA Taq polymerase, dNTPs, $\mathrm{MgCl}_{2}$ and PCR buffer), $5 \mu \mathrm{L}$ DNA template, $1 \mu \mathrm{L}$ of the forward and reverse primers (10 ng), and $6 \mu \mathrm{L}$ of nuclease free water was used for amplification. Polymerase chain reaction (PCR) was performed using MyCycler ${ }^{\mathrm{TM}}$ (Biorad, Cape Town, South Africa). The amplified products were separated on $1.5 \%$ agarose gel containing $5 \mu \mathrm{L}$ Ethidium bromide in $1 \times$ TAE buffer $\mathrm{pH} 8.0$ for $1 \mathrm{~h}$ at $100 \mathrm{~V}$ before being visualized and photographed under Alliance 4.7 transilluminator (UVITEC Limited, Cambridge, UK).

\section{Results}

\subsection{Study Population}

From 1100 meat and milk samples, a total of 134 samples were positive for S. aureus by culture, biochemical tests and molecular confirmed by polymerase chain targeting the $n u c$ gene. There were 
$102 / 500(20.4 \%)$ isolates from beef samples, 10/300 (3.3\%) from sheep samples, 14/100 (14\%) from pork samples were $8 / 200(4 \%)$ from milk samples. All of the 134 S. aureus revealed a 255 base pair size in an agarose gel electrophoresis.

\subsection{Antimicrobial Resistance Screening of S. aureus Isolates}

The resistance profiles of isolated S. aureus are shown in Table 2. Sheep and pork isolates were resistant to one to five antimicrobial agents. Multidrug resistance (MDR) among all S. aureus isolates was noted in penicillin G, oxacillin, clindamycin, erythromycin and tetracycline (Table 3).

Table 2 shows Staphylococcus aureus isolates resistant to penicillin G per sampling site. Resistance from isolates obtained from rump ranged from $40-62.9 \%$, flank ranged from $60-100 \%$, brisket from $50-100 \%$ and the neck from $20-100 \%$ from pork, sheep and beef isolates. A similar antibiotic resistance pattern was also observed for oxacillin, where isolates from rump ranged from $40-75 \%$, flank $50-100 \%$, brisket $50-100 \%$, and neck $20-100 \%$ while resistance to tetracycline was observed in isolates from rump ranging from $40-75 \%$, isolates from flank with percentages ranging from $45-50 \%$, brisket $25-50 \%$ and neck $20-50 \%$.

Table 2. Antibiotic resistance of Staphylococcus aureus isolates in beef, sheep and pork samples against 14 different antibiotics.

\begin{tabular}{|c|c|c|c|c|c|}
\hline \multicolumn{6}{|c|}{ Antimicrobial Resistance } \\
\hline Antibiotics & Rump $n p / n(\%)$ & Flank $n p / n(\%)$ & Brisket $n p / n(\%)$ & Neck $n p / n(\%)$ & Total $n p / n(\%)$ \\
\hline \multicolumn{6}{|c|}{ Penicillin G } \\
\hline Beef & $22 / 35(62.9)$ & $12 / 20(60)$ & $23 / 28(82.1)$ & $16 / 19(84.2)$ & $73 / 102(71.6)$ \\
\hline Sheep & $2 / 4(50)$ & $2 / 2(100)$ & $1 / 2(50)$ & $2 / 2(100)$ & $7 / 10(70)$ \\
\hline Pork & $2 / 5(40)$ & $0 / 0(0)$ & $4 / 4(100)$ & $1 / 5(20)$ & $7 / 14(50)$ \\
\hline \multicolumn{6}{|c|}{ Oxacillin/Methicillin } \\
\hline Beef & $23 / 35(65.7)$ & $10 / 20(50)$ & $16 / 28(57.1)$ & $19 / 19(100)$ & $68 / 102(66.7)$ \\
\hline Sheep & $3 / 4(75)$ & $2 / 2(100)$ & $1 / 2(50)$ & $1 / 2(50)$ & $7 / 10(70)$ \\
\hline Pork & $2 / 5(40)$ & $0 / 0(0)$ & $4 / 4(100)$ & $1 / 5(20)$ & $7 / 14(50)$ \\
\hline \multicolumn{6}{|c|}{ Tetracycline } \\
\hline Beef & $14 / 35(40)$ & $9 / 20(45)$ & $11 / 28(39.3)$ & $6 / 19(31.6)$ & $40 / 102(39.2)$ \\
\hline Sheep & $3 / 4(75)$ & $1 / 2(50)$ & $1 / 2(50)$ & $1 / 2(50)$ & $6 / 10(60)$ \\
\hline Pork & $0 / 5(0)$ & $0 / 0(0)$ & $1 / 4(25)$ & $1 / 5(20)$ & $2 / 14(14.3)$ \\
\hline \multicolumn{6}{|c|}{ Doxycycline } \\
\hline Beef & $9 / 35(25.7)$ & $5 / 20(25)$ & $6 / 28(21.4)$ & $6 / 19(31.6)$ & $26 / 102(25.5)$ \\
\hline Sheep & $2 / 4(50)$ & $0 / 2(0)$ & $0 / 2(0)$ & $0 / 2(0)$ & $2 / 10(20)$ \\
\hline Pork & $1 / 5(20)$ & $0 / 0(0)$ & $0 / 4(0)$ & $1 / 5(20)$ & $2 / 14(14.3)$ \\
\hline \multicolumn{6}{|c|}{ Minocycline } \\
\hline Beef & $4 / 35$ (11.4) & $3 / 20(15)$ & $2 / 28(7.1)$ & $4 / 19(21.1)$ & $13 / 102(12.7)$ \\
\hline Sheep & $1 / 4(25)$ & $0 / 2(0)$ & $0 / 2(0)$ & $0 / 2(0)$ & $1 / 10(10)$ \\
\hline Pork & $1 / 5(20)$ & $0 / 0(0)$ & $0 / 4(0)$ & $0 / 5(0)$ & $1 / 14(7.1)$ \\
\hline \multicolumn{6}{|c|}{ Erythromycin } \\
\hline Beef & $15 / 35(42.9)$ & $6 / 20(30)$ & $15 / 28(53.6)$ & $13 / 19(68.4)$ & $49 / 102(48)$ \\
\hline Sheep & $2 / 4(50)$ & $2 / 2(100)$ & $1 / 2(50)$ & $1 / 2(50)$ & $6 / 10(60)$ \\
\hline Pork & $1 / 5(20)$ & $0 / 0(0)$ & $2 / 4(50)$ & $1 / 5(20)$ & $4 / 14(28.6)$ \\
\hline \multicolumn{6}{|c|}{ Amikacin } \\
\hline Beef & $9 / 35$ (25.7) & $2 / 20(10)$ & $5 / 28(17.9)$ & $6 / 19$ (31.6) & $22 / 102(21.6)$ \\
\hline Sheep & $1 / 4(25)$ & $0 / 2(0)$ & $0 / 2(0)$ & $1 / 2(50)$ & $2 / 10(20)$ \\
\hline Pork & $0 / 5(0)$ & $0 / 0(0)$ & $0 / 4(0)$ & $0 / 5(0)$ & $0 / 14(0)$ \\
\hline \multicolumn{6}{|c|}{ Gentamicin } \\
\hline Beef & $1 / 35(2.9)$ & $2 / 20(10)$ & $2 / 28(7.1)$ & $5 / 19(26.3)$ & $10 / 102(9.8)$ \\
\hline Sheep & $2 / 4(50)$ & $1 / 2(50)$ & $0 / 2(0)$ & $2 / 2(100)$ & $5 / 10(50)$ \\
\hline Pork & $0 / 5(0)$ & $0 / 0(0)$ & $0 / 4(0)$ & $0 / 5(0)$ & $0 / 14(0)$ \\
\hline
\end{tabular}


Table 2. Cont.

\begin{tabular}{|c|c|c|c|c|c|}
\hline \multicolumn{6}{|c|}{ Antimicrobial Resistance } \\
\hline Antibiotics & Rump np/n (\%) & Flank $n p / n(\%)$ & Brisket $n p / n(\%)$ & Neck $n p / n(\%)$ & Total $n p / n(\%)$ \\
\hline \multicolumn{6}{|c|}{ Ciprofloxacin } \\
\hline Beef & $2 / 35(5.7)$ & $0 / 20(0)$ & $2 / 28(7.1)$ & $2 / 19(10.5)$ & $6 / 102(5.9)$ \\
\hline Sheep & $0 / 4(0)$ & $0 / 2(0)$ & $0 / 2(0)$ & $1 / 2(50)$ & 1/10 (10) \\
\hline Pork & $0 / 5(0)$ & $0 / 0(0)$ & $0 / 4(0)$ & $0 / 5(0)$ & $0 / 14(0)$ \\
\hline \multicolumn{6}{|c|}{ Clindamycin } \\
\hline Beef & $20 / 35(57.1)$ & $8 / 20(40)$ & $13 / 28(46.4)$ & $13 / 19(68.4)$ & $54 / 102(52.9)$ \\
\hline Sheep & $1 / 4(25)$ & $1 / 2(50)$ & $2 / 2(100)$ & $2 / 2(100)$ & $6 / 10(60)$ \\
\hline Pork & $1 / 5(20)$ & $0 / 0(0)$ & $2 / 4(50)$ & $0 / 5(0)$ & 8/14 (57.1) \\
\hline \multicolumn{6}{|c|}{ Chloramphenicol } \\
\hline Beef & $0 / 35(0)$ & $3 / 20(15)$ & $0 / 28(0)$ & $0 / 19(0)$ & $3 / 110(2.7)$ \\
\hline Sheep & $0 / 4(0)$ & $0 / 2(0)$ & $0 / 2(0)$ & $0 / 2(0)$ & $0 / 10(0)$ \\
\hline Pork & $0 / 5(0)$ & $0 / 0(0)$ & $0 / 4(0)$ & $1 / 5(20)$ & $1 / 14(7.1)$ \\
\hline \multicolumn{6}{|c|}{ Trimethoprim/sulfomethoxazole } \\
\hline Beef & $9 / 35(25.7)$ & $5 / 20(25)$ & $8 / 28(28.6)$ & $3 / 19(15.8)$ & $25 / 102(24.5)$ \\
\hline Sheep & $1 / 4(25)$ & $0 / 2(0)$ & $0 / 2(0)$ & $0 / 2(0)$ & $1 / 10(10)$ \\
\hline Pork & $1 / 5(20)$ & $0 / 0(0)$ & $1 / 4(25)$ & $0 / 5(0)$ & 2/14 (14.3) \\
\hline \multicolumn{6}{|c|}{ Ceftaroline } \\
\hline Beef & $5 / 35$ (14.3) & $5 / 20(25)$ & $9 / 28(32.1)$ & $5 / 19(26.3)$ & $24 / 102(23.5)$ \\
\hline Sheep & $1 / 4(25)$ & $0 / 2(0)$ & $0 / 2(0)$ & $0 / 2(0)$ & $1 / 10(10)$ \\
\hline Pork & $2 / 5(40)$ & $0 / 0(0)$ & $2 / 4(50)$ & $0 / 5(0)$ & 4/14 (28.6) \\
\hline \multicolumn{6}{|c|}{ Linezolid } \\
\hline Beef & $1 / 35(2.9)$ & $3 / 20(15)$ & $1 / 28(3.6)$ & $4 / 19(21.1)$ & 9/102 (8.8) \\
\hline Sheep & $0 / 4(0)$ & $0 / 2(0)$ & $0 / 2(0)$ & $0 / 2(0)$ & $0 / 10(0)$ \\
\hline Pork & $1 / 5(20)$ & $0 / 0(0)$ & $1 / 4(25)$ & $0 / 5(00$ & 2/14 (14.3) \\
\hline
\end{tabular}

$n p$ : number positive isolates, $n$ : number of collected isolates.

Multidrug-resistance was observed in 18 isolates from different farms and abattoirs. The pattern of resistance ranged from two antibiotics to nine antibiotics (Table 3).

Table 3. Multidrug resistance profiles of Staphylococcus aureus isolates to the tested.

\begin{tabular}{cccc}
\hline Isolates No. & Isolate Codes & Source & Resistance Pattern \\
\hline 1 & M13082 & Milk & CAZ-OXA-TET-MIN-PEN-G-CAM \\
2 & S9B & Sheep & OXA-PEN-G-ERY \\
3 & A12 & Beef & DOXY-OXA-TET-CLI-PEN-G-TMP-TMXERY \\
4 & PD1-Q & Pork & DOXY-OXA-TET-CLI-PEN-G-TMP-TMX-ERY \\
5 & CC5-Q & Beef & OXY-PEN-G \\
6 & C8D & Beef & OXY-PEN-G-ERY-GEN-TMP-TMX-CAM-CAZ \\
7 & B25 & Beef & CEF-OXA-MIN-PEN-G-GEN-TMP-TMX-ERY \\
8 & PA8-Q & Pork & CAZ-OXY-PEN-G-TMP-TMX \\
9 & C10 & Beef & DOXY-CAZ-AK-OXY-TET-PEN-G- ER \\
10 & PD5-Q & Pork & DOXY-OXA-PEN-G-ER-TET-GEN-TMP-TMX \\
11 & S1A & Sheep & DOXY-OXA-MIN-PEN-G-GEN \\
12 & A3-Q & Beef & DOXY-LZD-TET-PEN-G-CLI-TMP-TMX-ER \\
13 & PA6-Q & Pork & DOXY-LZD-CAZ-OXA-TET-MIN-PEN-G-CLI-ER \\
14 & $7 \mathrm{~B}$ & Beef & OXA-PEN-G-TET-ERY-GEN-CLI-CAM \\
15 & $8 A-Q$ & Beef & DOXY, TET, ERY \\
16 & D6-Q & Beef & DOXY-LZD-CAZ-TMP-TMX-ERY \\
17 & M8158 & Milk & CIP-DOXY-CAZ-TET-MIN-PEN-G-GEN-TMP-TMX \\
18 & D12 & Beef & OXA-PEN-GEN-CAM-TET \\
\hline
\end{tabular}

CIP: Ciprofloxacin, DOXY: Doxycycline, LZD: Linezoid, CAZ: Ceftazidime, AMK: Amikacin, OXA: Oxacillin, TET: Tetracycline, MIN: Minocycline, CAM: Chloramphenicol, PEN-G: Penicillin-G, CLI: Clindamycin, AMX: Amoxicillin, GEN: Gentamicin, TMP-SMX: Trimethoprim-sulfamethoxazole, ERY: Erythromycin. 
Among the 87 isolates resistant to different antibiotics, 65 different patterns were observed with 5 clusters. The patterns presented between 2 and 7 isolates. The remaining patterns were represented by single isolates (Figure 1).
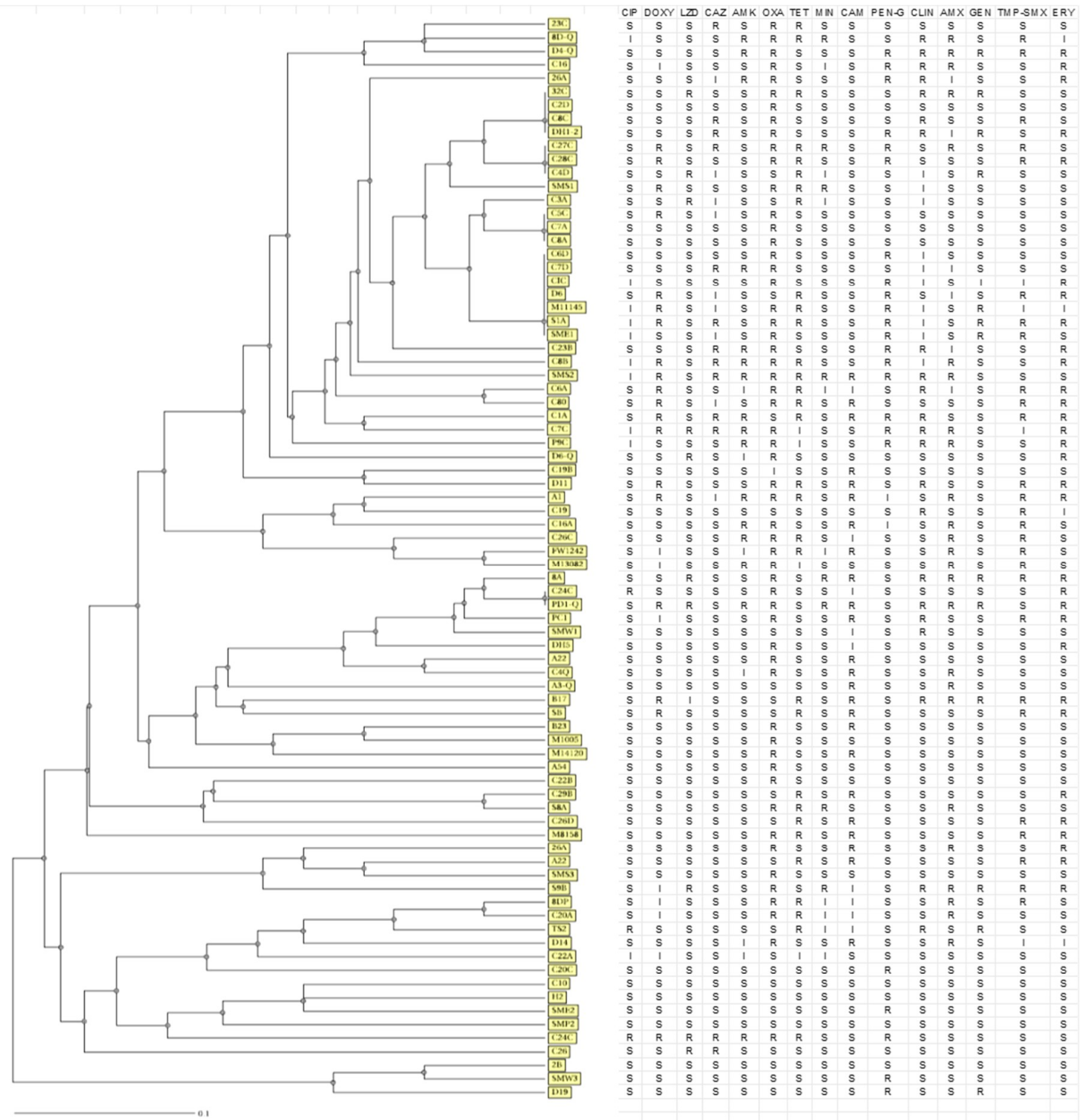

Figure 1. Dendrogram representing the similarity grouping of Staphylococcus aureus clusters based on their susceptibility profiles. The MIRU-VNTRplus service (www.miru-vntrplus.org) was used to compare isolates (resistance coded as 2 , susceptible as 1 and intermediate as 1 ). The differences in susceptibility profiles were used to estimate the distance. The strains were encoded and shown by numbers and letters highlighted in yellow. (CIP: Ciprofloxacin, Doxy: Doxycycline, LZD: Linezoid, CAZ: Ceftazidime, AMK: Amikacin, OXA: Oxacillin, TET: Tetracycline, MIN: Minocycline, CAM: Chloramphenicol, PEN-G: Penicillin-G, CLI: Clindamycin, AMX: Amoxicillin, GEN: Gentamicin, TMP-SMX: Trimethoprim-sulfamethoxazole, ERY: Erythromycin.)

\section{Detection of Resistance Genes}

Resistant genes detected ranged from $3.8 \%$ for tet $\mathrm{K}$ in sheep and $79.3 \%$ for tet $\mathrm{M}$ in beef. Sheep, pork and milk showed no detection of mecA, tetM, ant (4')-Ia and aph (3')-1-IIIa (Table 4). All other genes tested were not detected. 
Table 4. Resistant genes detected from Staphylococcus aureus isolated from the Eastern Cape Province.

\begin{tabular}{cccccc}
\hline Genes & Beef $\boldsymbol{n} \mathbf{( \% )}$ & Sheep $\boldsymbol{n}(\mathbf{\%})$ & Pork $\boldsymbol{n}(\mathbf{\%})$ & Milk $\boldsymbol{n} \mathbf{( \% )}$ & Total $\boldsymbol{n} \mathbf{( \% )}$ \\
\hline blaZ & $9(69.2)$ & $0(0)$ & $3(23.1)$ & $1(7.7)$ & $13(100)$ \\
mecA & $1(100)$ & $0(0)$ & $0(0)$ & $0(0)$ & $1(100)$ \\
tetK & $20(76.9)$ & $1(3.8)$ & $2(7.7)$ & $3(11.5)$ & $26(100)$ \\
tetM & $23(79.3)$ & $2(6.9)$ & $4(13.8)$ & $0(0)$ & $29(100)$ \\
msrA & $25(80)$ & $0(0)$ & $4(12.9)$ & $3(9.7)$ & $31(100)$ \\
ant $\left(4^{\prime}\right)-I a$ & $3(60)$ & $0(0)$ & $0(0)$ & $0(0)$ & $0(0)$ \\
aph $\left(3^{\prime}\right)-1-I I I a$ & $2(40)$ & $0(0)$ & $0(0)$ & $0(0)$ & $0(0)$ \\
\hline
\end{tabular}

\section{Discussion}

Antibiotic use drives the evolution of antibiotic resistance [33]. Our task is to preserve the effectiveness of existing antibiotics by minimizing the emergence and spread of multidrug resistant microorganisms to maximize the time until existing antibiotics become ineffective. Over the past years, the dissemination of antimicrobial resistance (AR) in bacteria, including staphylococci has increased and poses public health risks. This is best narrated by the multidrug resistant $S$. aureus strains that cause infections that are difficult to treat [38]. In this study the most $S$. aureus isolates were observed in beef samples and beef isolates showed resistance to several antibiotics including penicillin $\mathrm{G}(71.6 \%)$, oxacillin $(66.7 \%)$, clindamycin $(52.9 \%)$, erythromycin $(48 \%)$ and tetracycline $(39.2 \%)$ respectively. Sheep and pork samples were relatively resistant to one to five antimicrobial agents. The work conducted by Yang et al. [39] has reported similar levels of resistance of $S$. aureus isolates to penicillin, erythromycin and tetracycline [40,41]. Andreotti and Nicodeno [42] have revealed that the resistance of S. aureus to penicillin ranges from $20 \%$ to $100 \%$, whilst the percentage of resistance to other antibiotics was relatively lower. Most of the isolates in our study showed high sensitivity to several antibiotics including ciprofloxacin, chloramphenicol, clindamycin, linezolid and trimethoprim-sulfamethoxazole. This implies that such antibiotics can be used to treat infections caused by S. aureus. In our study, 65 different patterns were observed with 5 clusters among which, isolate Dh1-2 and 32C are from two different abattoirs while M11145 and SME1 were isolated from different farms isolated from milk. The patterns presented between 2 and 7 isolates. The remaining patterns were represented by single isolates. However, this is not a true reflection of clusters as only one aspect was used and no typing methods such as Pulse Field Gel Electrophoresis (PFGE), ribotyping and phagotyping were used.

In this study $82(67 \%)$ isolates showed phenotypic resistance to methicillin, however only one methicillin-resistant Staphylococcus aureus (MRSA) gene was detected using molecular methods. All the other isolates that showed resistance to oxacillin could have a mec $\mathrm{C}$ gene, which was not investigated in our study. Further studies need to be carried out to ascertain the involvement of the mecC gene in resistance of these isolates to oxacillin. A study performed by Diederen et al. [43] in the Netherlands has demonstrated that $2.5 \%$ of pork and beef samples harbored MRSA isolates. The research performed by Fessler and co-workers [44] has shown that MRSA were resistant to oxacillin, and $62.5 \%$ exhibited multidrug resistance. Similarly, the study of Hanson et al. [44] advocated that MRSA isolated from pork, beef, chicken and turkey were resistant to oxacillin and several other antibiotics. There were $87(69 \%)$ S. aureus isolates that were phenotypically resistant to penicillin G and only 13 (14.9\%) isolates were found to express the blaZ gene in this study. Disagreement can occur between phenotypic and genotypic resistance due to incomplete understanding of the genotypic basis of phenotypic resistance, flaws with the phenotypic or molecular (e.g., PCR) methods currently used to detect resistance. It may also be because the phenotypic resistance has been caused by point mutations, biofilm formation or antibiotic tolerance [36,45]. Different studies demonstrate the presence of other virulence factors that must be taken in consideration for a comprehensive evaluation of the risk. MRSA and MSSA can be considered parameters for the valuation of dedicated food chains: Poultry meats [46] and sheep (ovine food-chain) [47]. Specific genomic features, as pvl or mecC, were reported recently as emergent virulence factors in livestock in different papers [48,49]. 
Of the $82(67 \%)$ S. aureus isolates that were phenotypically resistant to oxacillin, only one isolate $(1.2 \%)$ was found to possess the mecA gene. This small proportion of isolates that showed amplification of the mecA gene compared to phenotypic resistance to oxacillin was not surprising. Oxacillin has been proposed as an alternative antibiotic for testing susceptibility/resistance to methicillin and to all $\beta$-lactams [50]. This could explain why all oxacillin-resistant isolates were not carrying the mec $\mathrm{A}$ gene, because they were showing resistance to $\beta$-lactams. Phenotypic resistance witnessed to oxacillin in this study could have been attained through other mechanisms, including the reduction in membrane permeability to $\beta$-lactam antibiotics.

Binding of tetracycline antibiotics to the $30 \mathrm{~S}$ ribosomal subunit prevents association of aminoacyl-tRNA with its acceptor site, thereby inhibiting protein synthesis [51]. S. aureus uses two mechanisms of tetracycline resistance; active efflux via tet $\mathrm{A}(K)$ and $\operatorname{tet} \mathrm{A}(L)$ and ribosomal protection via tet $\mathrm{A}(M)$ [51]. Tetracycline efflux in $S$. aureus strains is mediated by tet $\mathrm{A}(K)$, which is commonly carried by plasmid pT181. Integration of this plasmid into Type III SCCmec makes this kind of resistance to be named chromosomally encoded resistance. Resistance to tetracycline can also be mediated by mutations that cause increased expression of various chromosomally encoded efflux pumps, such as Tet38 [52,53]. In this study, a high detection rate was observed in tetM $29(46.7 \%)$ while tet $K$ detection rate was $26(41.9 \%)$ for tetracycline resistant genes. Seven $(11.3 \%)$ isolates contained both tet $\mathrm{K}$ and tet $\mathrm{M}$ gene.

The $\operatorname{erm}(\mathrm{C})$ determinant was found in 2 isolates (3.4\%) while no erm A and ermB were detected. These results are different from the results of Cetin et al. [54] who showed that ermA was the most prevalent phenotype among S. aureus. Macrolide antibiotic (including azithromycin, clarithromycin, erythromycin), resistance in $S$. aureus may be due to an active drug efflux mechanism encoded by $m s r \mathrm{~A}$ and $m s r \mathrm{~B}$ (conferring resistance to macrolides and type B streptogramins). In our study, $m s r \mathrm{~A}$ determinant was detected in $31(52.5 \%)$ isolates. It is likely that other erythromycin resistance genes such as msrA, Ere A-B or mef, which we did not include in our study, might be present among these isolates and account for the remainder of the isolates showing phenotypic resistance to erythromycin.

Aminoglycosides antibiotics play an important role in the treatment of staphylococcal infections [55]. Aminoglycosides inactivate antibiotics using aminoglycoside-modifying enzymes (AMEs) that are encoded by genetic elements [56,57]. The aac $\left(6^{\prime}\right)-I e+$ aph $\left(2^{\prime \prime}\right)$, ant $\left(4^{\prime}\right)-I a$, aph $\left(3^{\prime}\right)-I I I a$, and ant (6)-Ia genes that encode aminoglycoside- $6^{\prime}-\mathrm{N}$-acetyltransferase $/ 2^{\prime \prime}$-O-phosphoryltransferase, aminoglycoside-4'-O-nucleotidyltransferase I, aminoglyoside-3'-O-phosphoryltransferase III, and streptomycin modifying enzyme, respectively, are the most important genes in this regard. Resistance to gentamicin, kanamycin, and tobramycin in staphylococci is mediated by a bi-functional enzyme displaying AAC (6') and APH (2") activity [58]. In our study, we found 15 S. aureus isolates which were phenotypically resistant to gentamicin, however, only 5 (33.3\%) isolates were found to express one of these gentamicin resistance genes. Antibiotic resistance can be classified into three main categories: Intrinsic, adaptive, and acquired resistance [59]. We speculate that intrinsic antibiotic resistance, being the naturally low permeability of the bacterial cell wall, which limits uptake of many antibiotics including aminoglycosides is responsible for the other 10 isolates that did not show amplicons of the investigated target genes. We did not encounter any organism that was resistant to all tested antibiotics, implying that other tested antibiotics could still be used to inhibit the growth S. aureus in the from those four abattoirs and two farms investigated.

Although resistance to antibiotics were present, a characteristic typically reported in pork [18], the high proportion of multidrug resistance demonstrates how common S. aureus multidrug resistance is in the studied dairy farms and abattoirs. This development might be linked to numerous factors. Most dairy farmers in the region are not aware of the risks of $S$. aureus colonization to milk production and human health. Hygiene measures were not maintained before and after milking or slaughtering, which may expedite the presence of $S$. aureus on the skin of the udder and its access to the mammary gland and the different sites sampled. The importance of hygiene measures is highlighted in this study. 


\section{Conclusions}

Antibiotic misuse has determined resistance and S. aureus is widely implicated in antibiotic resistance transfer. However, better supervision and the proper application of hygienic practices in the transformation of raw materials of animal origin can reduce the spread of antibiotic resistance S. aureus. The distribution of antibiotic resistance is high in the Eastern Cape Province as compared to other areas where culling of infected animals is done. Usage of molecules in veterinary medicine and animal husbandry that are identical as, or closely associated to, antibiotics used in human medicine should be greatly discouraged.

Author Contributions: E.G. conceived and designed the experiments, edited the final draft; A.P. performed the experiments and wrote the draft manuscript.

Funding: This research was funded by South African National Research Foundation (NRF) grant number 87866 .

Acknowledgments: The authors would like to acknowledge the South African National Research Foundation (NRF) and the South African Medical Research Council (SAMRC) for funding this project and the University of Fort Hare for allowing them to conduct this research. We also want to thank Mr. Rudzani Manafe from the University of Johannesburg for providing the positive control for this study.

Conflicts of Interest: The authors declare no conflict of interest. The funders had no role in the design of the study; in the collection, analyses, or interpretation of data; in the writing of the manuscript, and in the decision to publish the results.

\section{References}

1. Evans, C.A.; Smith, W.M.; Johnston, E.A.; Giblett, E.R. Bacterial flora of the normal human skin. J. Investig. Dermatol. 1950, 15, 305-324. [CrossRef] [PubMed]

2. Neely, A.N.; Maley, M.P. Survival of enterococci and staphylococci on hospital fabrics and plastic. J. Clin. Microbiol. 2000, 38, 724-726. [PubMed]

3. Rasmussen, T.; Kirkeby, L.; Poulsen, K.; Reinholdt, J.; Kilian, M. Resident aerobic microbiota of the adult human nasal cavity. APMIS 2000, 108, 663-675. [CrossRef] [PubMed]

4. Guardabassi, L.; Schwarz, S.; Lloyd, D.H. Pet animals as reservoirs of antimicrobial-resistant bacteria Review. J. Antimicrob. Chemother. 2004, 54, 321-332. [CrossRef] [PubMed]

5. Nagase, N.; Sasaki, A.; Yamashita, K.; Shimizu, A.; Wakita, Y.; Kitai, S.; Kawano, J. Isolation and species distribution of staphylococci from animal and human skin. J. Vet. Med. Sci. 2002, 64, 245-250. [CrossRef] [PubMed]

6. Lee, J.H. Methicillin (oxacillin)-resistant Staphylococcus aureus strains isolated from major food animals and their potential transmission to humans. Appl. Environ. Microbiol. 2003, 69, 6489-6494. [CrossRef] [PubMed]

7. Abdalrahman, L.S.; Wells, H.; Fakhr, M.K. Staphylococcus aureus is more prevalent in retail beef livers than in pork and other beef cuts. J. Pathog. 2015, 4, 182-198. [CrossRef] [PubMed]

8. van Duijkeren, E.; Box, A.; Heck, M.; Wannet, W.; Fluit, A. Methicillin-resistant staphylococci isolated from animals. Vet. Microbiol. 2004, 103, 91-97. [CrossRef] [PubMed]

9. Acco, M.; Ferreira, F.S.; Henriques, J.A.P.; Tondo, E.C. Identification of multiple strains of Staphylococcus aureus colonizing nasal mucosa of food handlers. Int. J. Food Microbiol. 2003, 20, 489-493. [CrossRef]

10. Ateba, C.N.; Mbewe, M.; Moneoang, M.S.; Bezuidenhout, C.C. Antibiotic-resistant Staphylococcus aureus isolated from milk in the Mafikeng Area, North West province, South Africa. S. Afr. J. Sci. 2010, 106, 1-6. [CrossRef]

11. Lina, G.; Piémont, Y.; Godail-Gamot, F.; Bes, M.; Peter, M.O.; Gauduchon, V.; Vandenesch, F.; Etienne, J. Involvement of panton-valentine leukocidin-Producing Staphylococcus aureus in primary skin infections and pneumonia. Genet. Mol. Res. 1999, 29, 1128-1132. [CrossRef] [PubMed]

12. Le Loir, Y.; Baron, F.; Gautier, M. Staphylococcus aureus and food poisoning. Genet. Mol. Res. 2003, 2, 63-76. [PubMed]

13. Hageman, J.C.; Uyeki, T.M.; Francis, J.S.; Jernigan, D.B.; Wheeler, J.G.; Bridges, C.B.; Barenkamp, S.J.; Sievert, D.M.; Srinivasan, A.; Doherty, M.C. Severe community-acquired pneumonia due to Staphylococcus aureus, 2003-2004 influenza season. Emerg. Infect. Dis. 2006, 12, 894-899. [CrossRef] [PubMed] 
14. Hatakka, M.; Björkroth, K.J.; Asplund, K.; Mäki-Petäys, N.; Korkeala, H.J. Genotypes and Enterotoxicity of Staphylococcus aureus isolated from the Hands and Nasal Cavities of Flight-Catering Employees. J. Food Prot. 2000, 63, 1487-1491. [CrossRef] [PubMed]

15. Movassagh, M.H.; Shakoori, M.; Zolfaghari, J. The prevalence of Salmonella spp. In Bovine carcass at Tabriz slaughterhouse. Iran. Glob. Vet. 2010, 5, 146-149.

16. Olaoye, O.A. Meat: An overview of its composition, biochemical changes and associated microbial agents. Int. Food Res. J. 2011, 18, 877-885.

17. Nguyen, T.V.; Le Van, P.; Le Huy, C.; Gia, K.N.; Weintraub, A. Detection and characterization of diarrheagenic Escherichia coli from young children in Hanoi, Vietnam. J. Clin Microbiol. 2005, 43, 755-760. [CrossRef] [PubMed]

18. Pearce, R.A.; Bolton, D.J. Excision vs sponge swabbing-A comparison of methods for the microbiological sampling of beef, pork and lamb carcasses. J. Appl. Microbiol. 2005, 98, 896-900. [CrossRef] [PubMed]

19. Spanu, V.; Spanu, C.; Virdis, S.; Cossu, F.; Scarano, C.; de Santis, E.P.L. Virulence factors and genetic variability of Staphylococcus aureus strains isolated from raw sheep's milk cheese. Int. J. Food Microbiol. 2012, 153, 53-57. [CrossRef] [PubMed]

20. Valsangiacomo, C.; Dolina, M.; Peduzzi, R.; Jäggli, M. Antimicrobial susceptibility of Staphylococcus aureus isolates from hospitalized patients and dairy food (fresh cheese): A survey over a decade in southern Switzerland. Clin. Microbiol. Infect. 2000, 6, 393-394. [CrossRef]

21. Kitai, S.; Shimizu, A.; Kawano, J.; Sato, E.; Nakano, C.; Uji, T.; Kitagawa, H. Characterization of methicillin-resistant Staphylococcus aureus isolated from retail raw-chicken meat in Japan. J. Vet. Med. Sci. 2005, 67, 107-110. [CrossRef] [PubMed]

22. Umaru, G.A.; Kabir, J.; Umoh, V.J.; Bello, M.; Kwaga, J.K. Methicillin-resistant Staphylococcus aureus (MRSA) in fresh and fermented milk in Zaria and Kaduna, Nigeria. Int. J. Drug Res. Technol. 2017, 3, 8.

23. Akpaka, P.E.; Kissoon, S.; Rutherford, C.; Swantson, W.H.; Jayaratne, P. Evaluation of methods and costs for detecting methicillin-resistant Staphylococcus aureus isolates from clinical specimens at regional hospitals in Trinidad and Tobago. West Indian Med. J. 2008, 57, 24-27. [PubMed]

24. DeLeo, F.R.; Chambers, H.F. Reemergence of antibiotic-resistant Staphylococcus aureus in the genomics era. J. Clin. Investig. 2009, 119, 2464-2474. [CrossRef] [PubMed]

25. Que, Y.; Moreillon, P. Staphylococcus aureus (including Staphylococcal Toxic Shock). In Mandell Principles and Practice of Infectious Diseases, 7th ed.; Elsevier Churchill Livingstone: Philadelphia, PA, USA, 2015; pp. 2237-2271.

26. Esan, C.O.; Famurewa, O.; Lin, J.; Shittu, A.O. Characterization of Staphylococcus aureus isolates obtained from health care institutions in Ekiti and Ondo States, South-Western Nigeria. Afr. J. Microbiol. Res. 2009, 3, 962-968.

27. Caine, L.A.; Nwodo, U.U.; Okoh, A.I.; Ndip, R.N.; Green, E. Occurrence of virulence genes associated with diarrheagenic Escherichia coli isolated from raw cow's milk from two commercial dairy farms in the Eastern Cape Province, South Africa. Int. J. Environ. Res. Public Health 2014, 11, 11950-11963. [CrossRef] [PubMed]

28. Health Protection Agency. Staining Procedures. National Standard Method Issue 1. Available online: http:/ / www.hpa-standardmethods.org.uk/pdfsops.asp (accessed on 9 October 2018).

29. Health Protection Agency. Catalase Test. National Standard Method BSOP TP 8 Issue 2.1. Available online: http:/ / www.hpa-standardmethods.org.uk/pdfsops.asp (accessed on 9 October 2018).

30. Health Protection Agency. Oxidase Test. National Standard Method BSOP TP 26 Issue 2.1. Available online: http:/ / www.hpa-standardmethods.org.uk/pdf_sops.asp (accessed on 9 October 2018).

31. Maugeri, T.L.; Carbone, M.; Fera, M.T.; Irrera, G.P.; Gugliandolo, C. Distribution of potentially pathogenic bacteria as free living and plankton associated in a marine coastal zone. J. Appl. Microbiol. 2004, 97, 354-361. [CrossRef] [PubMed]

32. Clinical and Laboratory Standards Institute. Performance Standards for Antimicrobial Susceptibility Testing, 26th ed.; CLSI: Wayne, PA, USA, 2016.

33. zur Wiesch, P.A.; Kouyos, R.; Engelstädter, J.; Regoes, R.R.; Bonhoeffer, S. Population biological principles of drug-resistance evolution in infectious diseases. Lancet Infect. Dis. 2011, 11, 236-247. [CrossRef]

34. Olsen, J.E.; Christensen, H.; Aarestrup, F.M. Diversity and evolution of blaZ from Staphylococcus aureus and coagulase-negative staphylococci. J. Antimicrob. Chemother. 2006, 57, 450-460. [CrossRef] [PubMed] 
35. Roberts, M.C. Distribution of macrolide, lincosamide, streptogramin, ketolide and oxazolidinone (MLSKO) resistance genes in Gram-negative bacteria. Curr. Drug Targets Infect. Disord. 2004, 4, 207-215. [CrossRef] [PubMed]

36. Martineau, F.; Picard, F.J.; Lansac, N.; Ménard, C.; Roy, P.H.; Ouellette, M.; Bergeron, M.G. Correlation between the resistance genotype determined by multiplex PCR Assays and the antibiotic susceptibility patterns of Staphylococcus aureus and Staphylococcus epidermidis. Antimicrob. Agents Chemother. 2000, 44, 231-238. [CrossRef] [PubMed]

37. Choi, S.M.; Kim, S.H.; Kim, H.J.; Lee, D.G.; Choi, J.H.; Yoo, J.H.; Kang, J.H.; Shin, W.S.; Kang, M.W. Multiplex PCR for the detection of genes encoding aminoglycoside modifying enzymes and methicillin resistance among Staphylococcus species. J. Korean Med. Sci. 2003, 18, 631. [CrossRef] [PubMed]

38. Koning, S.; Van Belkum, A.; Snijders, S.; van Leeuwen, W.; Verbrugh, H.; Nouwen, J.; Op, M.; van Suijlekom-Smit, L.W.; van der Wouden, J.C.; Verduin, C. Severity of nonbullous Staphylococcus aureus impetigo in children is associated with strains harboring genetic markers for exfoliative toxin B, Panton-Valentine leukocidin, and the multidrug resistance plasmid pSK41. J. Clin. Microbiol. 2013, 41, 3017-3021. [CrossRef]

39. Strommenger, B.; Kettlitz, C.; Werner, G.; Witte, W. Multiplex PCR assay for simultaneous detection of nine clinically relevant antibiotic resistance genes in Staphylococcus aureus. J. Clin. Microbiol. 2003, 41, 4089-4094. [CrossRef] [PubMed]

40. Yang, X.; Zhang, J.; Yu, S.; Wu, Q.; Guo, W.; Huang, J.; Cai, S. Prevalence of Staphylococcus aureus and Methicillin-Resistant Staphylococcus aureus in Retail Ready-to-Eat Foods in China. Front. Microbiol. 2016, 7, 816. [CrossRef] [PubMed]

41. De Oliveira, A.P.; Watts, J.L.; Salmon, S.A.; Aarestrup, F.M. Antimicrobial susceptibility of Staphylococcus aureus isolated from bovine mastitis in Europe and the United States. J. Dairy Sci. 2001, 83, 855-862. [CrossRef]

42. Rajala-Schultz, P.J.; Smith, K.L.; Hogan, J.S.; Love, B.C. Antimicrobial susceptibility of mastitis pathogens from first lactation and older cows. Vet. Microbiol. 2004, 102, 33-42. [CrossRef] [PubMed]

43. Andreotti, R.; Nicodemo, M.L.F. Use of Antimicrobials in Bovine Production and Development of Resistance; Embrapa Gado de Corte: Campo Grande, Brazil, 2004.

44. Diederen, B.M.W.; van Loo, I.H.M.; Woudenberg, J.H.C.; Roosendaal, R.; Verhulst, C.; van Keulen, P.H.J.; Kluytmans, J.A. Low prevalence of non-typable methicillin-resistant Staphylococcus aureus in meat products in the Netherlands. Emerg. Infect. Dis. 2007, 13, 1753-1755.

45. Fessler, A.; Scott, C.; Kadlec, K.; Ehricht, R.; Monecke, S.; Schwarz, S. Characterization of methicillin-resistant Staphylococcus aureus ST398 from cases of bovine mastitis. J. Antimicrob. Chemother. 2010, 65, 619-625. [CrossRef] [PubMed]

46. Abdalrahman, L.S.; Stanley, A.; Wells, H.; Fakhr, M.K. Isolation, Virulence, and Antimicrobial Resistance of Methicillin-Resistant Staphylococcus aureus (MRSA) and Methicillin Sensitive Staphylococcus aureus (MSSA) Strains from Oklahoma Retail Poultry Meats. Int. J. Environ. Res. Public Health 2015, 12, 6148-6161. [CrossRef] [PubMed]

47. Macori, G.; Giacinti, G.; Bellio, A.; Gallina, S.; Bianchi, D.M.; Sagrafoli, D.; Marri, N.; Giangolini, G.; Amatiste, S.; Decastelli, L. Molecular Epidemiology of Methicillin-Resistant and Methicillin-Susceptible Staphylococcus aureus in the Ovine Dairy Chain and in Farm-Related Humans. Toxins 2017, 9, 161. [CrossRef] [PubMed]

48. Agabou, A.; Ouchenane, Z.; Ngba Essebe, C.; Khemissi, S.; Chehboub, M.T.E.; Chehboub, I.B.; Sotto, A.; Dunyach-Remy, C.; Lavigne, J.-P. Emergence of nasal carriage of ST80 and ST152 PVL+ Staphylococcus aureus isolates from livestock in Algeria. Toxins 2017, 9, 303. [CrossRef] [PubMed]

49. Papadimitriou-Olivgeris, M.; Drougka, E.; Fligou, F.; Dodou, V.; Kolonitsiou, F.; Filos, K.S.; Anastassiou, E.D.; Petinaki, E.; Marangos, M.; Spiliopoulou, I. Spread of Tst-Positive Staphylococcus aureus strains belonging to ST30 clone among patients and healthcare workers in two intensive care units. Toxins 2017, 9, 270. [CrossRef] [PubMed]

50. Croes, S.; Deurenberg, R.H.; Boumans, M.L.L.; Beisser, P.S.; Neef, C.; Stobberingh, E.E. Staphylococcus aureus biofilm formation at the physiologic glucose concentration depends on the Staphylococcus aureus lineage. BMC Microbiol. 2009, 9, 229. [CrossRef] [PubMed] 
51. Baker-Austin, C.; Wright, M.S.; Stepanauskas, R.; McArthur, J.V. Co-selection of antibiotic and metal resistance. Trends Microbiol. 2006, 14, 176-182. [CrossRef] [PubMed]

52. Kwong, S.M.; Lim, R.; Lebard, R.J.; Skurray, R.A.; Firth, N. Analysis of the pSK1 replicon, a prototype from the staphylococcal multi-resistance plasmid family. Microbiology 2008, 154, 3084-3094. [CrossRef] [PubMed]

53. Novick, R.P.; Roth, C. Plasmid-linked Resistance to Inorganic Salts in Staphylococcus aureus. J. Bacteriol. 1968, 95, 1335-1342. [PubMed]

54. Kuehnert, M.J.; Hill, H.A.; Kupronis, B.A.; Tokars, J.I.; Solomon, S.L.; Jernigan, D.B. Methicillin-resistantStaphylococcus aureus hospitalizations, United States. Emerg. Infect. Dis. 2005, 11, 468. [CrossRef] [PubMed]

55. Hauschild, T.; Sacha, P.; Wieczorek, P.; Zalewska, M.; Kaczyñska, K.; Tryniszewska, E. Aminoglycosides resistance in clinical isolates of Staphylococcus aureus from a University Hospital in Bialystok, Poland. Folia Histochem. Cytobiol. 2008, 46, 225-228. [CrossRef] [PubMed]

56. Chopra, I.; Roberts, M. Tetracycline antibiotics: Mode of action, applications, molecular biology, and epidemiology of bacterial resistance. Microbiol. Mol. Biol. Rev. 2001, 65, 232-260. [CrossRef] [PubMed]

57. Jensen, S.O.; Lyon, B.R. Genetics of antimicrobial resistance in Staphylococcus aureus. Future Microbiol. 2009, 4, 565-582. [CrossRef] [PubMed]

58. Cetin, E.S.; Gunes, H.; Kaya, S.; Aridogan, B.C.; Demirci, M. Distribution of genes encoding resistance to macrolides, lincosamides and streptogramins among clinical staphylococcal isolates in a Turkish university hospital. J. Microbiol. Immunol. Infect. 2010, 43, 524-529. [CrossRef]

59. Schmitz, F.J.; Fluit, A.C.; Gondolf, M.; Beyrau, R.; Lindenlauf, E.; Verhoef, J.; Heinz, H.P.; Jones, M.E. The prevalence of aminoglycoside resistance and corresponding resistance genes in clinical isolates of staphylococci from 19 European hospitals. J. Antimicrob. Chemother. 1999, 43, 253-259. [CrossRef] [PubMed]

(C) 2018 by the authors. Licensee MDPI, Basel, Switzerland. This article is an open access article distributed under the terms and conditions of the Creative Commons Attribution (CC BY) license (http:/ / creativecommons.org/licenses/by/4.0/). 